\title{
Application of nanotechnology in technological processes of animal husbandry in Ukraine
}

\author{
N. Boltianska' ${ }^{1}$, I. Manita², H. Podashevskaya ${ }^{3}$ \\ 1,2 Dmytro Motornyi Tavria state agrotechnological university (Melitopol, Ukraine) \\ ${ }^{3}$ Belarusian State Agrarian Technical University (Minsk, Belarus) \\ e-mail: 1nataliia.boltianska@tsatu.edu.ua, ${ }^{2}$ igor.manita@tsatu.edu.ua, ${ }^{3}$ confamf@tut.by
}

\begin{abstract}
Today, it is becoming more and more obvious that those countries that develop electronics, nanotechnology and biotechnology will have an advantage. The studies carried out have shown that the use of nanotechnology and nanomaterials in animal husbandry currently allows solving a number of acute problems and provides a significant effect. In animal husbandry, it is advisable to use nanotechnology in technological processes, where they provide additional advantages. When forming the microclimate in the premises for keeping animals and poultry, the use of nanotechnology makes it possible to replace the energy-intensive supply and exhaust ventilation system with an energy-saving air conditioning system while ensuring the regulatory parameters of the microclimate: temperature, humidity, gas composition, microbial content, dustiness, air velocity, eliminating odors while maintaining the heat release of animals. Nanoelectrotechnology in the technological processes of poultry farming using high and medium-high frequency electromagnetic radiation allows for: ultraviolet irradiation of hatching eggs and young poultry in order to decontaminate them from pathogens and stimulate perinatal (during incubation) development of young animals (studies have shown that hatchability of chickens increases to 94 , and their preservation is up to $99 \%$ ); disinfection and pasteurization of eggs; division of young poultry by sex. Taking into account the problems of environmental pollution, emissions with an unpleasant smell and gases affecting global warming, existing in animal husbandry, the most effective at present is the use of film-forming solutions of catalytic action. A promising development is the development of environmentally friendly nanotechnology for electroconservation of silage mass of green fodder with an electroactivated preservative instead of expensive organic acids, which require strict safety measures.
\end{abstract}

Keywords: agriculture, animal husbandry, nanotechnology, technological process, poultry farming, microclimate, ecology.

Formulation of the problem. At the present stage, the nanoindustry has been identified as one of the most innovative areas. Nanotechnology and nanomaterials are used in many areas of human activity, the number nanoproducts produced in the world are increasing every year. The use of the achievements of the nanoindustry is in the interests of the state agrarian policy. Nanotechnology is beginning to be successfully applied in genetic and cellular engineering, animal treatment; improving the quality of feed; technical service of agricultural machinery. Nanotechnologies are aimed at solving urgent problems of the agro-industrial complex, such as resource saving and increasing the efficiency of equipment, increasing the productivity of animal husbandry, productivity and resistance of agricultural crops to adverse environmental conditions, improving technological processes of production and processing of agricultural raw materials, obtaining environmentally friendly products and eliminating the loss of product quality supply during storage [1-3].

Analysis of recent research. Analysis of the state of the domestic infrastructure of the nanotechnology industry, which was carried out by V. B. Borisevich, B. V. Borisevich, V. G. Kaplunenko, M. M. Khomin, R. S. Fedoruk, S. Y. Kropivka shows that, despite the high quality of research and the created scientific and technical groundwork, the infrastructure of the nanotechnology industry in Ukraine is still far behind the world leaders in nanotechnology. Various elements of the infrastructure were created, the functioning of which, to a greater extent, is aimed at generating new knowledge, and not at the commercialization of the results of scientific activities [4-8]. The main direction of the further development of animal husbandry is its all-round intensification with the use of nanotechnology.

Formulation of the goals of the article. To analyze the development of nanotechnology in agriculture of developed countries and determine the appropriate directions for their implementation in the technological processes of animal husbandry in Ukraine.

Main part. The use of nanotechnology and nanomaterials in animal husbandry currently allows solving a number of acute problems and provides a significant effect. In animal husbandry, it is advisable 
to use nanotechnology in technological processes, where they provide additional advantages. When forming the microclimate in the premises for keeping animals and poultry, it allows replacing the energyintensive supply and exhaust ventilation system with an energy-saving air conditioning system (electrochemical purification) of air with the provision of the standard microclimate parameters: temperature, humidity, gas composition, microbiological seeding, dustiness, air velocity, elimination of odors while preserving animal heat As a result of the search for a solution to the problem, a recirculating cleaning system in a nanosecond corona discharge (NCD) was developed [9-12].

The technological process is that dirty and warm air during ventilation is not carried out into the environment, but passes through a pulsed corona electrostatic precipitator, where gases are converted, dust is deposited and bacteria and viruses are neutralized. To remove reaction products and residual ozone, the air passes through wet cleaning in the form of a microdispersed water aerosol. The aerosol is precipitated by a constant voltage corona filter. Clean air is supplied to the room. The process of cleaning exhaust gases from various organic and inorganic impurities, including various odors of an organic and inorganic nature, takes place in an electrostatic precipitator when it is powered by short high-voltage voltage pulses superimposed on a high constant voltage. The duration of the impulses is from tens of nanoseconds to several thousand $[13,14]$.

As a result, the particles enter into radiationchemical reactions with pollutant molecules. In the course of the reaction, gaseous impurities are converted into ecologically harmless gaseous products - aerosols or solid products, while the converted products are charged. Gaseous oxides of nitrogen or sulfur are converted to aerosols of the corresponding acids. Organic compounds decompose to the simplest compounds $\left(\mathrm{CO}_{2}, \mathrm{H}_{2} \mathrm{O}\right)$ or form the simplest organic acids. Removal of aerosols and solid particles from the air flow is carried out in the pauses between pulses, due to the applied constant voltage. Aromatic oils can be added to the water aerosol to sanitize the premises. Then the presence of ozone in emissions is not observed at all, since it enters into a bond with hydrocarbons, and a pleasant aroma is felt in the air [15-17]. The purified and flavored air is fed back to the livestock or poultry houses. If necessary, fresh air is taken from the street, which is precleaned (Fig. 1).

Such a fully purified air recirculation system consumes less energy than typical ventilation systems and, moreover, similar purification systems. This is achieved through the use of corona filters, new aerosol generators and the lack of ventilation. Studies show that energy consumption per head is reduced 56 times per year (from 2.4 to 0.4 thousand kWh).
With the expansion of the construction of pig farms by 110,500 thousand heads, the presence of ammonia and carbon dioxide in the air, which reaches the maximum permissible concentration of MPC $(0.02 \mathrm{mg} / \mathrm{I})$ in the summer, is especially dangerous for young animals. Electrochemical purification of polluted air without release into the environment was carried out by passing it through a nanodispersed solution of water with slaked lime. Nanoelectric technology in the technological processes of poultry farming using high and microwave electromagnetic radiation allows you to:

- ultraviolet irradiation of hatching eggs and young poultry in order to decontaminate them from pathogens and stimulate the perinatal (during the incubation period) development of young birds. Studies have shown that hatchability of chickens increases to 94 , and their safety - up to $99 \%$;

- disinfection and pasteurization of eggs and egg products;

- division of young poultry by sex.

At present, an environmentally friendly nanotechnology is being developed for the electroconservation of the silage mass of green fodder with an electroactivated preservative (EAC) instead of expensive organic acids that require strict safety measures. EAC on the basis of electrolysis of $1 \%$ sodium chloride solution increases feed safety up to $95 \%$. Taking into account the existing problems of environmental pollution, emissions with an unpleasant odor and gases affecting global warming in animal husbandry, the most effective at present is the use of film-forming solutions of catalytic action. The nanoparticles of titanium, silver and silicon (TiO2, $\mathrm{Ag}$, and $\mathrm{SiO} 2$ ) embedded in the structure of these solutions exhibit hitherto unknown properties. Catalytic films stimulate oxidation and reduction reactions on their surfaces and in their immediate surroundings. In livestock farms, oxidation can be used to deodorize and reduction reactions to limit the emission of ammonia and nitrogen oxides.

The use of drugs that cause catalysis of the medium, for example, photocatalysts based on $\mathrm{TiO}_{2}$, makes it possible to use the following functions in agriculture: hydrophilic effect, self-cleaning, bactericidal, fungicidal and disinfecting, neutralizing volatile organic compounds. The use of catalytic oxides with the participation of silver nanoparticles makes it possible to obtain a catalytic effect without access to light and to enhance the bactericidal, fungicidal and sterilizing functions. All of these functions can be used in the construction of outbuildings. Their effective implementation in agricultural practice will improve animal welfare and zoological conditions, limit burdens on the environment and reduce environmental hazards caused by gas emissions from intestinal fermentation and waste. 


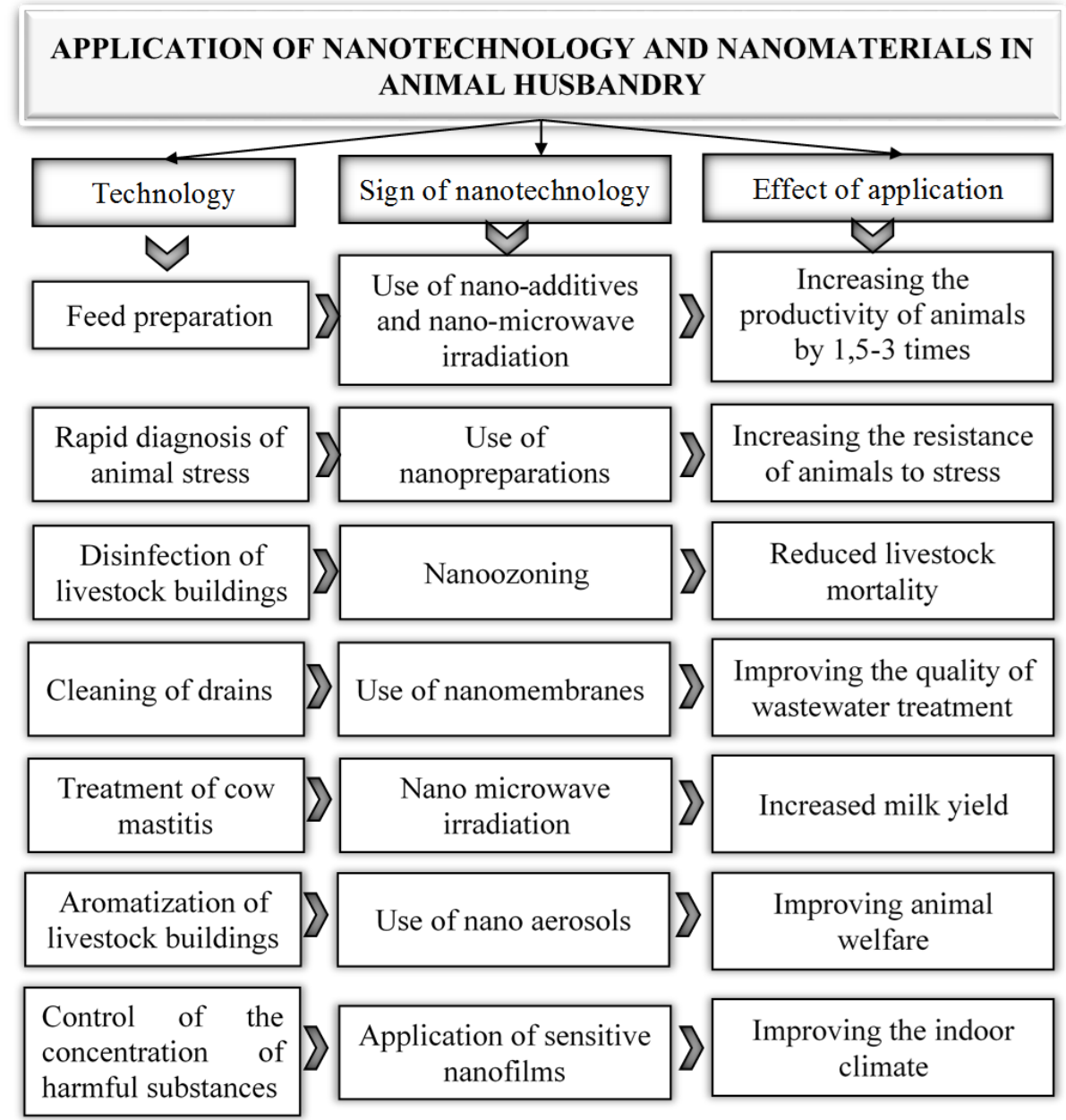

Fig. 1. Application of nanotechnology and nanomaterials in animal husbandry

Today, it is becoming more and more obvious that those countries that develop electronics, nanotechnology and biotechnology will have an advantage. Ukraine has large internal reserves, as there is a significant scientific backlog from Soviet times in nanoscience.

Summary. The use of nanotechnology and nanomaterials in animal husbandry currently allows solving a number of acute problems and provides a significant effect. In animal husbandry, it is advisable to use nanotechnology in technological processes, where they provide additional advantages. When forming the microclimate in the premises for keeping animals and poultry, it allows replacing the energyintensive supply and exhaust ventilation system with an energy-saving air conditioning system (electrochemical purification) of air with the provision of standard microclimate parameters: temperature, humidity, gas composition, microbiological contamination, dustiness, air velocity, elimination of odors while maintaining heat release from animals.

Nanoelectrotechnology in technological processes of poultry farming using high and microwave electromagnetic radiation allows for: ultraviolet irradiation of hatching eggs and young poultry in order to decontaminate them from pathogens and stimulate the perinatal (during the incubation period) development of young animals. (studies have shown that hatchability of chickens increases to 94 , and their safety - up to $99 \%$ ); disinfection and pasteurization of eggs and egg products; division of young poultry by sex.

Taking into account the existing problems of environmental pollution, emissions with an unpleasant odor and gases affecting global warming in animal husbandry, the most effective at present is the use of film-forming solutions of catalytic action.

\section{References:}

1. Allkemper, T., Bremer, C., Matuszewski, L., Ebert, W., Reimer, P. (2012). Contrast-enhanced blood-pool MR angiography with optimized iron oxides: effect of size and dose on vascular contrast enhancement in rabbits. Radiology, 223 (2), pp. 432 - 438. 
2. Sklar, O. G. (2018). Fundamentals of designing livestock enterprises: a textbook. Condor Publishing House. $380 \mathrm{p}$.

3. Komar, A. S. (2018). Analysis of the design of presses for the preparation of feed pellets and fuel briquettes. TDATU Scientific Bulletin. Issue 8. Vol. 2. pp. 44-56.

4. Tsuchiya, K., Nitta, N., Sonoda, A., Otani, H., Takahashi, M., Murata, K. (2013), Atherosclerotic imaging using 4 types of superparamagnetic iron oxides: new possibilities for mannan-coated particles. Eur. J. Radiol. 82 (11), pp. 1919-1925.

5. Boltyanskaya, N. I. (2017). The dependence of the competitiveness of the pig industry from itchnology parameters of productivity of the animals. Bulletin of Kharkov national University-University of agriculture after Petro Vasilenko. Kharkov. Vol. 18. pp.81-89.

6. Komar, A. S. (2019). Processing of poultry manure for fertilization by granulation. Abstracts of the 5th International Scientific and Practical Conference «Innovative Technologies for Growing, Storage and Processing of Horticulture and Crop Production». Uman. pp.18-20.

7. Skliar, A., Boltyanskyi, B. (2019). Research of the cereal materials micronizer for fodder components preparation in animal husbandry. Modern Development Paths of Agricultural Production. Springer Nature Switzerland AG. pp. 249-258.

8. Boltyansky, O. V. (2012). The development of the pig industry and the competitiveness of its products. MOTROL: Motoryzacja i Energetyka Rolnictwa. Vol. 14, No 3. pp. 164-175.

9. Zhang, Y. X., Das, G. K., Xu R. Tan, T. T. Y. (2009). Tb-doped iron oxide: bifunctional fluorescent and magnetic nanocrystals. J. Mater. Chem. 19 (22). pp. 3696-3703.
10. Komar, A. S. (2019). Development of the design of a press-granulator for the processing of bird manure. Coll. scientific-works of Intern. Research Practice Conf. «Topical issues of development of agrarian science in Ukraine». pp. 84-91.

11. Boltyansky, B. (2016). Analysis of major errors in the design of pumping stations and manure storage on pig farms. TEKA Commission of Motorization and Energetics in Agriculture. Vol.16, No 2. pp. 49-54.

12. Selvan, S. T., Patra, P. K., Ang, C. Y., Ying, J. Y. (2017). Synthesis of silica-coated semiconductor and magnetic quantum dots and their use in the imaging of live cells. Angew Chem. Int. Ed. Engl. 46 (14), pp. 2448-2452

13. Sklar, O. (2012). Mechanization of technological processes in animal husbandry: textbook. manual. Melitopol: Color Print. 720 p.

14. Boltyanskaya, N. I. (2016). The system of factors of effective application resurser-Gauci technologies in dairy cattle in the enterprise. Scientific Bulletin Tauride state agrotechnological University. Electronic scientific specialized edition. Vol. 6. pp. 55-64.

15. . Syrvatka, V. J., Slyvchuk, Y. I., Rozgoni, I. I. 92013) Chemical synthesis of silver nanoparticles with attractive physicochemical properties. International OSA Network of student IONS-14, Torun, Poland, p. 29.

16. Singh, S. P., Rahman, M. F., Murty, U. S., Mahboob, M., Grover, P. (2013). Comparative study of genotoxicity and tissue distribution of nano and micron sized iron oxide in rats after acute oral treatment. Toxicol. Appl. Pharmacol., 266 (1), pp. 56-66

17. Boltyansky, O. V. (2016). Analysis of the main areas of resource conservation in animal husbandry. Motrol: Motoryzacja i Energetyka Rolnictwa. Vol. 18, No 13. pp. 49-54.

\section{Аннотація}

\section{Застосування нанотехнологій в технологічних процесах тваринництва України}

\section{Н. Болтянська, І. Маніта, О. Подашевська}

На сьогоднішній день все більш очевидним стає, що перевага буде у тих країн, які розвивають електроніку, нанотехнології та біотехнології. Проведені дослідження показали, що застосування нанотехнологій і наноматеріалів в тваринництві в даний час дозволяє вирішити ряд гострих проблем і забезпечує значний ефект. У тваринництві нанотехнології доцільно використовувати в технологічних процесах, де вони дають додаткові переваги. При формуванні мікроклімату в приміщеннях утримання тварин і птиці застосування нанотехнологій дозволяє замінити енергоємну припливно-витяжну систему вентиляції енергозберігаючою системою кондиціонування повітря із забезпеченням нормативних параметрів мікроклімату: температура, вологість, газовий склад, мікробіообсіменінність, запиленість, швидкість руху повітря, усунення запахів із збереженням тепловиділень тварин. Наноелектротехнологія в технологічних процесах птахівництва з використанням електромагнітних випромінювань високої і понадвисокої частоти дозволяє здійснювати: ультрафріолетове опромінення інкубаційних яєць і молодняку птиці з метою їх знезараження від хвороботворних мікроорганізмів і стимуляції перинатального (в період інкубації) розвитку молодняка (дослідження показали, що виводимість курчат зростає до 94, а їх збереження - до 99\%); знезараження та пастеризацію яєць і яйцепродуктів; поділ молодняку птиці по підлозі. 3 огляду на існуючі в тваринництві проблеми забруднення 
навколишнього середовища, емісій з неприємним запахом і газів, що впливають на глобальне потепління, найбільш ефектним в даний час $є$ застосування плівкоутворюючих розчинів каталітичного дії. Перспективною є розробка екологічно чистої нанотехнології електроконсервуваннія силосної маси зелених кормів електроактивованним консервантом замість дорогих органічних кислот, які потребують дотримання суворих заходів техніки безпеки.

Ключові слова - сільське господарство, тваринництво, нанотехнології, технологічний процес, птахівництво, мікроклімат, екологія.

\section{Аннотация \\ Применение нанотехнологий в технологических процессах животноводства Украины}

\section{Н. Болтянская, И. Манита, Е. Подашевская}

На сегодняшний день все более очевидным становится, что преимущество будет у тех стран, которые развивают электронику, нанотехнологии и биотехнологии. Проведенные исследования показали, что применение нанотехнологий и наноматериалов в животноводстве в настоящее время позволяет решить ряд острых проблем и обеспечивает значительный эффект. В животноводстве нанотехнологии целесообразно использовать в технологических процессах, где они дают дополнительные преимущества. При формировании микроклимата в помещениях содержания животных и птицы применение нанотехнологий позволяет заменить энергоёмкую приточно-вытяжную систему вентиляции энергосберегающей системой кондиционирования воздуха с обеспечением нормативных параметров микроклимата: температура, влажность, газовый состав, микробообсемененность, запыленность, скорость движения воздуха, устранения запахов с сохранением тепловыделений животных. Наноэлектротехнология в технологических процессах птицеводства с использованием электромагнитных излучений высокой и средневысокой частоты позволяет осуществлять: ультрафиолетовое облучение инкубационных яиц и молодняка птицы с целью их обеззараживания от болезнетворных микроорганизмов и стимуляции перинатального (в период инкубации) развития молодняка (исследования показали, что выводимость цыплят возрастает до 94, а их сохраняемость - до 99\%); обеззараживания и пастеризацию яиц; разделение молодняка птицы по полу. Учитывая существующие в животноводстве проблемы загрязнения окружающей среды, эмиссий с неприятным запахом и газов, влияющих на глобальное потепление, наиболее эффективным в настоящее время является применение пленкообразующих растворов каталитического действия. Перспективной является разработка экологически чистой нанотехнологии электроконсервирования силосной массы зеленых кормов электроактивированным консервантом вместо дорогих органических кислот, которые требуют соблюдения строгих мер техники безопасности.

Ключевые слова - сельское хозяйство, животноводство, нанотехнологии, технологический процесс, птицеводство, микроклимат, экология.

\section{Бібліографічне посилання/ Bibliography citation: Harvard}

Boltianska, N., Manita, I. and Podashevskaya, H. (2020) 'Application of nanotechnology in technological processes of animal husbandry in Ukraine', Engineering of nature management, (2(16), pp. 33 - 37.

Подано до редакції / Received: 22.08.2020

ISSN 2311-1828

http://enm.khntusg.com.ua
Інженерія природокористування, 2020, №2(16), с. 33 - 37

Engineering of nature management, 2020, \#2(16), p. 33 - 37 